\title{
Hepatomegaly with neutropenia: a girl with glycogen storage disease $\mathrm{lb}$
}

\author{
Deepanjan Bhattacharya, Anil Kumar BN, Inusha Panigrahi, ${ }^{\circledR}$ Anupriya Kaur
}

Department of Paediatrics, Post Graduate Institute of Medical Education and Research (PGIMER), Chandigarh, India

\section{Correspondence to} Dr Inusha Panigrahi, inupan@yahoo.com

Accepted 15 May 2019

\section{DESCRIPTION}

A 15-month-old girl, born to a second-degree consanguineous marriage, presented with history of recurrent respiratory tract infections over past 6 months, which required in-hospital treatment with intravenous antibiotics and respiratory support. There was no history of diarrhoea, ear or skin infections or failure to gain weight. There was history of hypoglycaemic seizures in neonatal period and he expired due to sepsis at 8 months of age.

On examination, she was a well-thriving child with sparse hypopigmented hair (figure 1A). Her abdomen was distended with firm hepatomegaly (span $15 \mathrm{~cm}$ ), without any evidence of splenic enlargement or free fluid. Rest of systemic examination was unremarkable.

Investigations revealed neutropenia (haemoglobin $87 \mathrm{~g} / \mathrm{L}$, total leucocyte count (TLC) $6.7 \times 10^{9} / \mathrm{L}$, absolute neutrophil count (ANC) $871 /$ $\mathrm{mm}^{3}$, platelet count $306 \times 10^{9} / \mathrm{L}$ ) and elevated transaminases: aspartate aminotransferase (AST) 248 IU/L and alanine aminotransferase (ALT) $128 \mathrm{IU} / \mathrm{L}$ respectively. He also had hyperlipidaemia (serum cholesterol $332 \mathrm{mg} / \mathrm{dL}$, triglycerides $1845 \mathrm{mg} / \mathrm{dL}$ ), hyperuricaemia $(7.8 \mathrm{mg} / \mathrm{dL})$ and elevated lactate $(4.7 \mathrm{mmol} / \mathrm{L})$ levels. Ultrasound of abdomen revealed enlarged liver $(15.3 \mathrm{~cm})$ as well as kidneys $(8.5 \mathrm{~cm})$. Hair microscopy was unremarkable, and workup for immunodeficiency (primary and secondary) was negative.

Histopathological examination of liver showed macro and microvesicular steatosis and vacuolated granular cytoplasm, consistent with glycogen storage disease. In view of associated neutropenia, a possibility of glycogen storage disease type Ib (GSD Ib) was considered.

DNA analysis by targeted next-generation sequencing revealed two variants in the SLC37A4 gene, consistent with the clinical diagnosis. The genetic analysis revealed NM_001164279.1: del

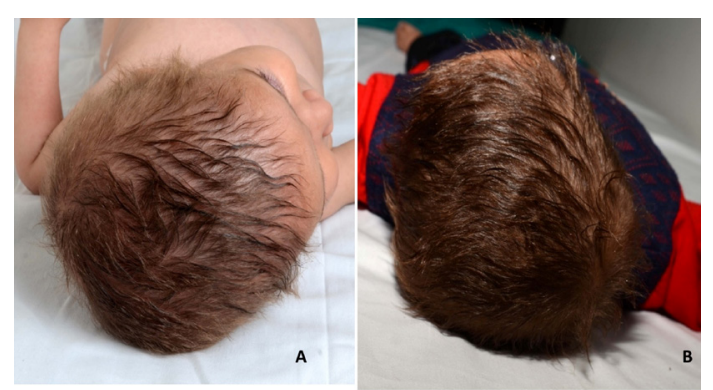

Figure 1 Colour photograph showing hair colour before (A) and after corn starch therapy (B).
C, in SLC37A4 gene-in homozygous state in the child. There was also another variant-an indel: $171+117$ TCTC $>$ C of doubtful significance, also in homozygous state. No significant RMRP gene variants were observed in the patient.

She was started on uncooked corn starch, and co-trimoxazole prophylaxis. On follow-up, there was improvement in colour and texture of her hair (figure 1B), decrease in hepatomegaly as well as increase in neutrophil count (haemoglobin $94 \mathrm{~g} / \mathrm{L}$, TLC $8.77 \times 10^{9} / \mathrm{L}$, ANC $2240 / \mathrm{mm}^{3}$, platelet count $328 \times 10^{9} / \mathrm{L}$ ) and liver enzymes (AST $60 \mathrm{IU} / \mathrm{L}$, ALT $56 \mathrm{IU} / \mathrm{L})$.

Glycogen storage disorder (GSD) type $\mathrm{Ib}$ is a variant of GSD type I, accounting for $20 \%$ of cases. It results from mutation of G6PT1 gene (SLC37A4), located on chromosome 11q23, which encodes glucose-6-phosphate translocase. It was first described by Senior and Loridan in 1968, as a functional deficiency of glucose-6-phosphatase, ${ }^{1}$ leading to increased glycogen accumulation in liver and kidneys, further leading to enlargement.

Recurrent infections and neutropenia is a distinctive feature of GSD Ib, as neutrophils show signs of apoptosis with increased caspase activity, condensation of nuclei and mitochondrial clustering with translocation of pro-apoptotic BCL2 protein BAX. ${ }^{2}$

Uncooked corn starch is the mainstay of therapy in GSD since 1980s, helping to maintain normoglycaemia. It has drastically improved quality of life and clinical outcome of patients over the last three decades. $^{3}$

Neutropenia in GSD type Ib usually requires therapy with recombinant granulocyte/monocyte colony-stimulating factor or granulocyte colony-stimulating factor, which results in improvement of mean neutrophil count and reduction of infections and enterocolitis, though it carries risk of myeloid neoplasms. ${ }^{4}$ Other modalities

\section{Learning points}

- Glycogen storage disorder (GSD), especially type Ib, can present with recurrent infections, mimicking primary immunodeficiency.

- Corn starch is the mainstay of treatment in GSD.

- Although recombinant colony stimulating factors (granulocyte/monocyte colonystimulating factor and granulocyte colonystimulating factor) are used for neutropenia, there may be a role of corn starch in improving neutrophil count. 
include allogenic hematopoietic stem cell or orthotopic liver transplant.

Contributors DB: patient management, literature review and preparation of the initial draft of the manuscript. AKBN: patient management, literature review and revision of the initial draft of the manuscript. IP: clinician-in-charge and guarantor, critical review of the manuscript for important intellectual content and final approval of the version to be published. AK: critical review of the manuscript for important intellectual content and final approval of the version to be published.

Funding The authors have not declared a specific grant for this research from any funding agency in the public, commercial or not-for-profit sectors.

Competing interests None declared.
Patient consent for publication Parental/guardian consent obtained.

Provenance and peer review Not commissioned; externally peer reviewed.

\section{REFERENCES}

1 Narisawa $\mathrm{K}$, Otomo $\mathrm{H}$, Igarashi $\mathrm{Y}$, et al. Glycogen storage disease type $1 \mathrm{~b}$ due to a defect of glucose-6-phosphate translocase. J Inherit Metab Dis 1982;5:227-8.

2 Chou JY, Jun HS, Mansfield BC. Neutropenia in type Ib glycogen storage disease. Curr Opin Hematol 2010;17:36-42.

3 Correia CE, Bhattacharya K, Lee PJ, et al. Use of modified cornstarch therapy to extend fasting in glycogen storage disease types la and Ib. Am J Clin Nutr 2008;88:1272-6.

4 Dale DC, Bolyard AA, Marrero TM, et al. Neutropenia In Glycogen Storage Disease 1b (GSD1b). Blood 2013;122:2265.

Copyright 2019 BMJ Publishing Group. All rights reserved. For permission to reuse any of this content visit https://www.bmj.com/company/products-services/rights-and-licensing/permissions/

BMJ Case Report Fellows may re-use this article for personal use and teaching without any further permission.

Become a Fellow of BMJ Case Reports today and you can:

- Submit as many cases as you like

- Enjoy fast sympathetic peer review and rapid publication of accepted articles

- Access all the published articles

Re-use any of the published material for personal use and teaching without further permission

Customer Service

If you have any further queries about your subscription, please contact our customer services team on +44 (0) 2071111105 or via email at support@bmj.com.

Visit casereports.bmj.com for more articles like this and to become a Fellow 